\title{
Gibberellic acid provides greater tolerance to saline stress in cactus seed germination
}

\author{
Ayslan Trindade Lima*, Beatriz Araújo Oliveira and Marcos Vinicius Meiado
}

Federal University of Sergipe, Itabaiana, SE, Brazil.

*Author for correspondence: tl.ayslan@gmalil.com

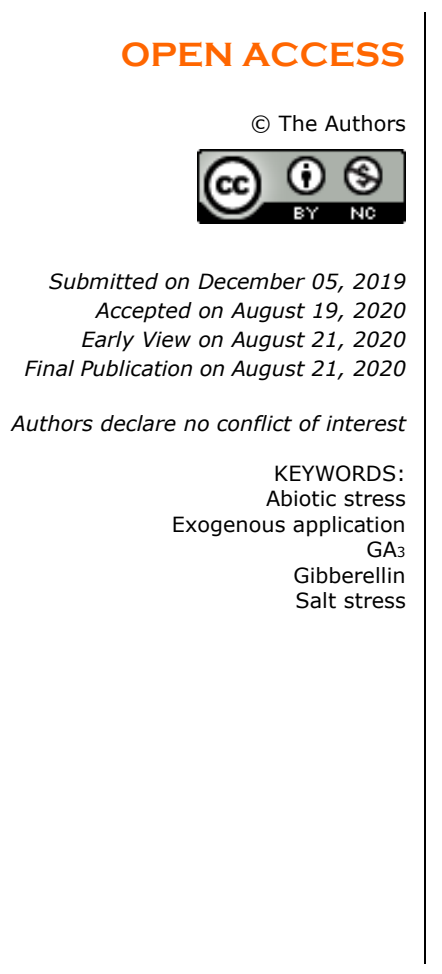

\section{ABSTRACT}

It is important to understand the ecophysiological behavior and develop techniques applicable to conservation measures of species that inhabit arid and semi-arid ecosystem and are exposed to adverse environmental conditions. The objective of this study was to evaluate the effects of gibberellic acid $\left(\mathrm{GA}_{3}\right)$ application during seed germination under saline stress conditions of a cactus. Pilosocereus gounellei susbp gounellei seeds were submitted to $\mathrm{NaCl}$ saline solutions at osmotic potentials of $0.0,-0.3,-0.6$ and $-0.9 \mathrm{MPa}$. For each osmotic potential, $\mathrm{GA}_{3}$ concentrations of $0,100,200$ and $300 \mathrm{ppm}$ were used. The results indicated that salt stress reduces germination percentage and synchronization as seeds are submitted to more negative osmotic potentials, as well as delaying germination time. However, this negative effect of $\mathrm{NaCl}$ was reversed when the seeds were subjected to the specific concentration of $100 \mathrm{ppm}$ of gibberellic acid. Therefore, our study demonstrated that the application of $\mathrm{GA}_{3}$ at specific concentration improves the germinative metabolism of cactus seeds and promotes the acquisition of tolerance to saline stress conditions by increasing germinability, reducing germination time and increasing synchronization, thus representing a viable technique for seed germination and seedlings production under adverse environmental conditions.

\section{Highlighted Conclusions}

1. The application of $\mathrm{GA}_{3}$ at specific concentration improves the germinative metabolism of cactus seeds and promotes the acquisition of tolerance to saline stress conditions.

2. The application of $\mathrm{GA}_{3}$ represents a viable technique for seed germination and seedlings production under adverse environmental conditions.

\section{INTRODUCTION}

Gibberellic acid (GA) is a plant hormone that is involved in various stages of plant development, such as seed germination, leaf expansion, stem growth and flowering (Ryu and Cho 2015). During germination, this phytohormone plays an important role promoting hydrolysis in the cell wall of seed coat cells, allowing embryo expansion and root protrusion (Steinbrecher and Leubner-Matzger 2017). The role of GAs in plant metabolism under abiotic stress conditions is becoming increasingly evident, the negative effects of stress may be related to low GA production or the plants inability to respond to this hormone effects (Llanes et al. 2016).

Soil salinization is a frequent problem in arid and semi-arid ecosystems of the globe, which can negatively influence the dynamics of the native plant community (Santos et al. 2018). The development in environments with these characteristics depends on the ability of plant species to adapt to negative osmotic potentials due to high salt concentrations (Cabot et al. 2014). Seed germination is a crucial phase in the plant life cycle, completely dependent on environmental conditions and determinant in the success of species propagation (Donohue et al. 2010, Rajjou et al. 2012). Salt stress negatively affects all stages of plant development (Flowers et al. 2010), whether due to ion toxicity, ionic imbalance in metabolism, or water deficit caused by salt content (Marschner 1995).

In the view of the above, it is important to understand the ecophysiological behavior and develop techniques applicable to conservation measures of species that inhabit this type of ecosystem and are exposed to adverse environmental conditions. Pilosocereus gounellei (F.A.C.Weber) Byles \& Rowley subsp. gounellei (Cactaceae) has an important ecological role in the vegetative communities in which it occurs due to its adaptations to the limiting 
conditions of the environment. Popularly known as xique-xique or alastrado, the species is widely distributed in areas of Caatinga, a Dry Tropical Forest of Northeastern Brazil, establishing in different soil types or rocky outcrops. (Taylor and Zappi 2004, Meiado et al. 2015). The seeds of $P$. gounellei subsp. gounellei germinate only in the presence of light, being classified as positive photoblastics and the ideal germination temperature of this species is between 30 and $35^{\circ} \mathrm{C}$. (Meiado et al. 2016). Thus, the objective of this study was to evaluate the effects of gibberellic acid application during $P$. gounellei susbp. gounellei seeds germination under saline stress conditions.

\section{MATERIAL AND METHODS}

Seed collection. We collected the seeds in May 2019 in the municipality of Caninde de São Francisco, Sergipe State, Northeast Brazil $\left(9^{\circ} 38^{\prime} 12.6^{\prime \prime S} 37^{\circ} 46^{\prime} 24.0^{\prime \prime W}\right)$. The area has BSh climate according to the climate classification of Köppen and Geiger, with annual average temperature of $25.3 \stackrel{\circ}{\circ}$. The average annual rainfall is $521 \mathrm{~mm}$. The region is characterized by four months with rainfall above $60 \mathrm{~mm}$ (rainy season) and eight months without rain or with rainfall below this value (dry season), with October being the driest month and May the most precipitation during the year.

We collected ripe fruits from 15 individuals of $P$. gounellei subsp. gounellei. The individuals we selected were separated by a minimum distance of $100 \mathrm{~m}$ to avoid the choice of clone individuals, which would reduce genetic variability. We opened the fruits manually and placed the seeds to dry in plastic trays at room temperature until the funicular pulp was completely dehydrated. After this procedure, we manually removed the dehydrated funicular pulp from the seeds, washed them in running water and dried them at room temperature (Gomes et al. 2017).

Germination tests and parameters evaluated. We evaluated the germination of $P$. gounellei subsp. gounellei using distilled water (control $-0.0 \mathrm{MPa}$ ) and under osmotic potentials of $-0.3 ;-0.6$ and $-0.9 \mathrm{MPa} \mathrm{NaCl}$ solution (Braccini et al. 1996) for salt stress simulation. For the preparation of each saline solution, we used gibberellic acid $\left(\mathrm{GA}_{3}\right)$ hormonal solutions at concentrations of 0 (control), 100, 200 and $300 \mathrm{ppm}$. In each treatment, we used four replicates with 25 seeds, which we placed to germinate in $5 \mathrm{~cm}$ diameter Petri dishes, containing two layers of filter paper moistened with $1.5 \mathrm{~mL}$ of the solution corresponding to the treatment. We sealed the Petri dishes with transparent plastic and kept them under white light, with a $12 \mathrm{~h}$ photoperiod and a temperature of $30{ }^{\circ} \mathrm{C}$. We counted the number of seeds germinated daily, for a period of 30 days, and considered root protrusion as seed germination criterion (Meiado et al. 2016).

At the end of the experiment, we calculated the germinability $(G=(N / 100) 100$, where $N=$ number of germinated seeds at the end of the test. Unit:\%), the mean germination time $\left[\bar{t}=\sum_{i=1}^{k} n_{i} t_{i} / \sum_{i=1}^{k} n_{i}\right.$, where $t_{i}$ is the period from the beginning of the experiment to the nth observation, $n_{i}$ is the number of seeds germinated at time $i$ (not the accumulated number but the number corresponding to the nth observation) and $k$ the last germination time. Unit: days], the coefficient of variation of germination time $\left(C V_{t}=\left(s_{t} / \vec{t}\right) 100\right.$, where $s_{t}$ is the standard deviation of the average germination time and $\bar{t}$ is the mean germination time. Unit: \%), the mean germination rate $\left(\bar{v}=1 / \bar{t}\right.$, where $\bar{t}$ is the mean germination time. Unit: days $\left.{ }^{-1}\right)$ and the uncertainty or synchronization index $\left(U=-\sum_{i=1}^{k} f_{i} \log _{2} f_{i}\right.$; where $f_{i}=n_{i} / \sum_{i=1}^{k} n_{i} ; n_{i}$ is the number of seeds germinated in the nth time. Unit: Bits) (Ranal and Santana 2006, Ranal et al. 2009). We checked the normality of the data residues and the homogeneity of the variances of all germinative parameters by the Shapiro-Wilk and Levene tests, respectively. Subsequently, we subjected the data to a two-way ANOVA (osmotic potential and $\mathrm{GA}_{3}$ concentration) with a posteriori Tukey test. We performed all statistical analyzes using STATISTICA 13 software, with a significance index $<0.05$.

\section{RESULTS}

We observed that $\mathrm{GA}_{3}$ concentration $(\mathrm{F}=7.820, \mathrm{df}=3, \mathrm{p}=0.0002)$ and osmotic potential $(\mathrm{F}=39.335, \mathrm{df}=3, \mathrm{p}$ $<0.0000$ ) affect the seed germinability of $P$. gounellei subsp. gounellei. Seeds showed a reduction of about $30 \%$ in germinability when under the influence of the most negative osmotic potential $(-0.9 \mathrm{MPa})$, at 200 and $300 \mathrm{ppm}$ gibberellin concentrations. However, when we subjected the seeds to $100 \mathrm{ppm}$ at the same osmotic potential $(-0.9$ $\mathrm{MPa})$, the seeds maintained their high germination percentage, which justifies the significant interaction between the two factors that we observed when we analyzed germinability $(F=6.207, d f=9, p<0.0001$; Figure $1 A)$.

We also observed an influence of $\mathrm{GA}_{3}$ concentration $(\mathrm{F}=6.659$, $\mathrm{df}=3, \mathrm{p}=0.0007)$ and osmotic potential $(\mathrm{F}=$ 17.105, $\mathrm{df}=3, \mathrm{p}<0.0000)$ on the mean germination time as well as an interaction between these two factors $(F=$ $2.775, \mathrm{df}=9, \mathrm{p}=0.0106)$. Higher concentrations of gibberellic acid (200 and $300 \mathrm{ppm})$ promoted germination delay 
of 4.7 and 3.5 days, respectively, when compared to the treatment of $100 \mathrm{ppm} \mathrm{GA}$ at the same osmotic potential, as shown in Figure 1B. In turn, the seeds that were submitted to $100 \mathrm{ppm}$ concentration maintained the average germination time similar to the seeds of the control treatment, even under more severe salt stress conditions.
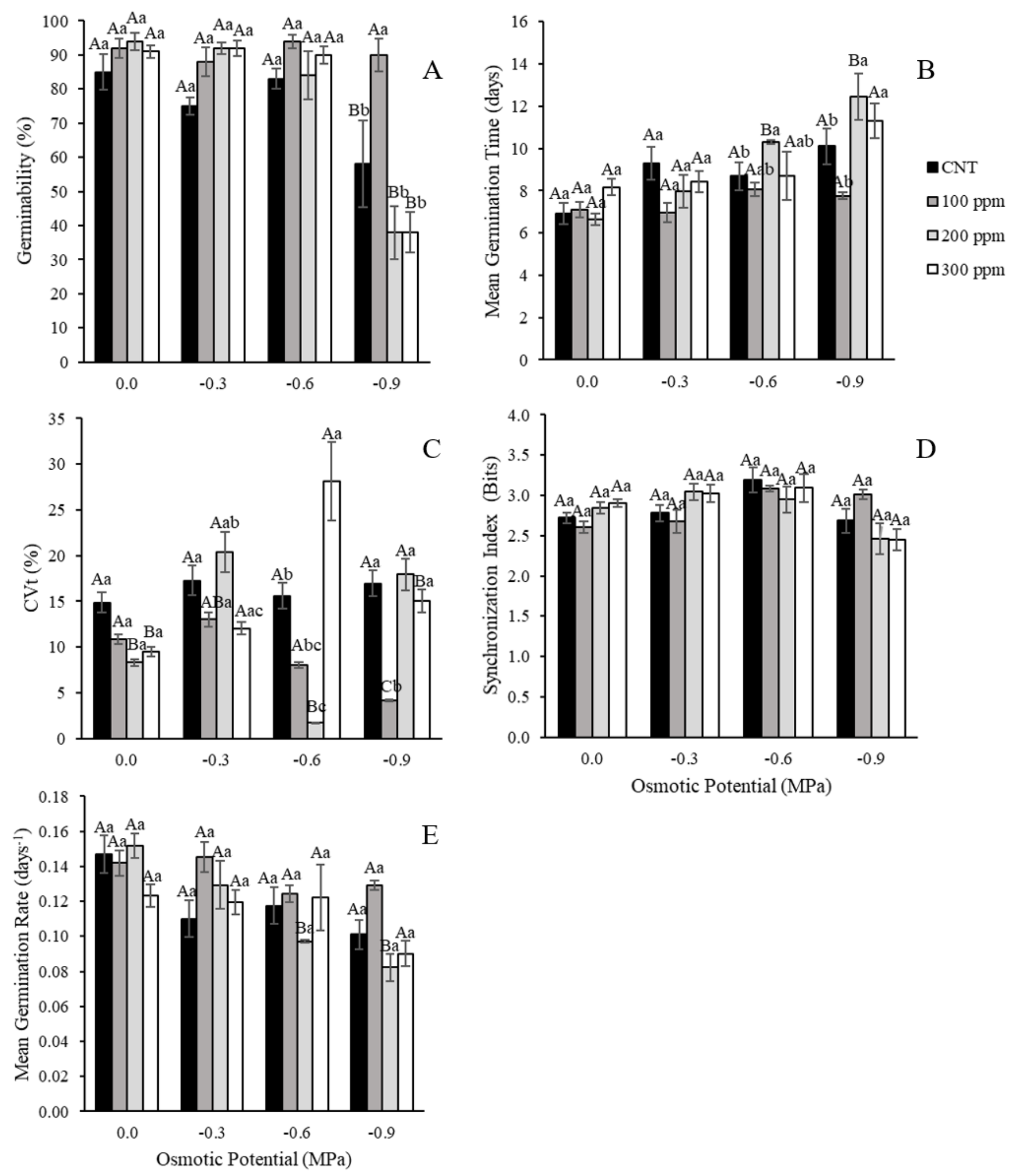

Figure 1. Germinability (\%) (A), Mean Germination Time (days) (B), Coefficient of Variation of Germination Time (\%) (C), Synchronization Index (Bits) (D) and Mean Germination Rate (days ${ }^{-1}$ ) (E) of Pilosocereus gounellei (F.A.C.Weber) Byles \& Rowley subsp. gounellei (Cactaceae) seeds germination under different concentrations of $\mathrm{NaCl}(\mathrm{MPa})$ and Acid Gibberellic $(\mathrm{ppm})$ solutions. CNT = control $(0 \mathrm{ppm})$. Data are expressed as mean \pm error. Capital letters compare gibberellin concentration in different osmotic potentials and lowercase letters compare different gibberellin concentration in the same osmotic potentials. 
Regarding the mean germination rate parameter, we found a pattern of influence similar to the other parameters, where the increase of $\mathrm{GA}_{3}$ concentration $(F=4.574$, $\mathrm{df}=3, \mathrm{p}=0.0067)$ and the reduction of osmotic potential $(F=13.600, d f=3, p<0.0001)$ reduced the mean germination rate. The significant interaction between the two factors we evaluated indicates that the influence of salinity on mean germination rate was not similar at all $\mathrm{GA}_{3}$ concentrations $(\mathrm{F}=2.232$, df $=9, \mathrm{p}=0.0358)$, a fact that we found when we found an mean germination rate similar to the control $\left(0.15 \pm 0.01\right.$ days $\left.^{-1}\right)$ in seeds we subjected to a concentration of $100 \mathrm{ppm} \mathrm{GA}$ and an osmotic potential of $-0.9 \mathrm{MPa}\left(0.13 \pm 0.01\right.$ days $^{-1}$, Figure $\left.1 \mathrm{E}\right)$.

Osmotic potential $(F=6.538, d f=3, p=0.0008)$ and $\mathrm{GA}_{3}$ concentrations $(F=20.655, \mathrm{df}=3, \mathrm{p}<0.0001)$ also affected the coefficient of variation of germination time. In more negative osmotic potentials $(-0.6$ and $-0.9 \mathrm{MPa})$, the 100 and $200 \mathrm{ppm}$ concentrations of the hormone solution provided a reduction in the high seed germination heterogeneity over time compared to the control and $300 \mathrm{ppm}$ in these same saline potentials. The significant interaction between the two factors we evaluated also indicates that reduction in the high seed germination heterogeneity over time provided by the reduction in osmotic potential did not occur similarly at all $\mathrm{GA}_{3}$ concentrations $(F=20.436, d f=3, p<0.0001$, Figure $1 C)$.

Unlike all the other parameters we described above, $\mathrm{GA}_{3}$ concentration did not affect the germination synchronization index $(F=0.078, d f=3, p=0.9716$; Figure $1 D)$. However, the reduction in osmotic potential provided an increase in synchronization index at all $\mathrm{GA}_{3}$ concentrations $(F=9.257, \mathrm{df}=3, \mathrm{p}=0.0001)$, which indicates that salinity provides seed germination desynchronization. In addition, we also found a significant interaction between $\mathrm{GA}_{3}$ concentration and osmotic potential, indicating that the influence of osmotic potentials on germination synchronization did not occur similarly among all $\mathrm{GA}_{3}$ concentrations we evaluated.

\section{DISCUSSION}

Natural environments with salinized soils such as Caatinga prevent seed germination both by water restriction, which is imposed on the seeds due to a more negative external osmotic potential, and by the metabolic deregulation provided by the toxicity of $\mathrm{Na}^{+}$and $\mathrm{Cl}^{-}$ions (Kaya et al. 2006). This explains the reduced germinability of $P$. gounellei subsp. gounellei that we observed in saline stress conditions, as well as the increased of the mean germination time and the increased of the coefficient of variation of germination time, with consequent reduction of germination synchronization. Lima and Meiado (2017), in studies with Pilosocereus catingicola (Gürke) Byles \& G.D. Rowley subsp. salvadorensis (Werderm.) Zappi (Cactaceae), also demonstrated that treatments with higher $\mathrm{NaCl}$ concentrations negatively influenced the water absorption by the seeds, reducing germination and prolonging the time required for the germination process to occur completely.

The addition of specific concentration of exogenous $\mathrm{GA}_{3}(100 \mathrm{ppm})$ provided an increase in seed tolerance to saline stress conditions and this fact can be observed by the high germination percentage in negative osmotic potentials, in addition to the optimization of germination time under high salinity with presence of $\mathrm{GA}_{3}$, where seeds reduced the mean germination time and the coefficient of variation of germination time.

The presence of $\mathrm{GA}_{3}$ in saline solutions reduced the damage of $\mathrm{NaCl}$ to the seeds, providing greater water absorption or reducing the amount of water required for the germination process to occur. Iqbal et al. (2011) pointed out that under abiotic stress conditions, specific concentrations of $\mathrm{GA}_{3}$ may improve the metabolism, as this phytohormone regulates the metabolic process by signaling enzymes classified as antioxidants, which play a role in eliminating reactive oxygen species, which reduces oxidative stress and consequently conferring greater tolerance and reduces the damage effect of abiotic stresses. In addition, Siddiqui et al. (2008) demonstrated that the improvement in metabolism is related to the increase in levels of $\mathrm{GA}_{1}$ and $\mathrm{GA}_{4}$ bioactive molecules, whereas there is a reduction in the levels of abscisic acid, plant hormone involved in seed dormancy and reduction of metabolism under stress conditions.

Kaur et al. (1998), in studies with Cicer arietinum L. (Fabaceae) seeds, demonstrated that salt stress conditions reduced the germination percentage due to physiological imbalances, such as reduced amylase activity. These enzymes, such as $\alpha$-amylase and $\beta$-amylase, have their production stimulated by gibberellin released naturally by the embryo during the germination process and are important in the seed endosperm degradation process (Oliveira et al. 2013).

Saline stress conditions reduce the amount of naturally synthesized gibberellin by embryos during germination process (Llanes et al. 2016). In the present study, the presence of exogenous $\mathrm{GA}_{3}$ in saline solutions may have led to an increase in endogenous gibberellin availability and activity of enzymes responsible for reserve tissue degradation, resulting in a return to normal levels of germination percentage and mean germination time. On the other hand, seeds of $P$. gounellei susbp. gounellei, when exposed the highest concentrations of $\mathrm{GA}_{3}$ in $\mathrm{NaCl}$ solutions, kept their germinability reduced and higher values of coefficient of variation of germination time. This 
indicates that excess of $\mathrm{GA}_{3}$ can also cause metabolic imbalance and act synergistically at high salt concentrations, further impairing the physiological stages of the germination process.

Therefore, our study demonstrated that the application of $\mathrm{GA}_{3}$ at specific concentration improves the germinative metabolism of cactus seeds and promotes the acquisition of tolerance to saline stress conditions by increasing germinability, reducing germination time and increasing synchronization, thus representing a viable technique for seed germination and seedlings production under adverse environmental conditions

\section{References}

Braccini AL et al. 1996. Germinação e vigor de sementes de soja sob estresse hídrico induzido por soluções de cloreto de sódio, manitol e polietileno glicol. Revista Brasileira de Sementes 18:10-16.

Cabot $\mathrm{C}$ et al. 2014. Lessons from crop plants struggling with salinity. Plant Science 226:2-13.

Donohue K et al. 2010. Germination, post germination adaptation, and species ecological ranges. Annual Review of Ecology, Evolution and Systematics 41:293-319.

Flowers TJ et al. 2010. Evolution of halophytes: multiple origins of salt tolerance in land plants. Functional Plant Biology 37:604-612.

Gomes VGN et al. 2017. Synchronous fruiting and common seed dispersers of two endemic columnar cacti in the Caatinga, a Dry Forest in Brazil. Plant Ecology 218:1325-1338.

Iqbal $\mathrm{N}$ et al. 2011. Role of gibberellins in regulation of source-sink relations under optimal and limiting environmental conditions. Current Science 100:998-1007.

Kaur S et al. 1998. Gibberellin $\mathrm{A}_{3}$ reverses the effect of salt stress in chickpea (Cicer arietinum L.) seedlings by enhancing amylase activity and mobilization of starch in cotyledons. Plant Growth Regulation 26:85-90.

Kaya MD et al. 2006. Seed treatment to overcome salt and drought stress during germination in sunflower (Helianthus annuus L.). European Journal of Agronomy 24:291-295.

Lima AT and Meiado MV. 2017. Discontinuous hydration alters seed germination under stress of two populations of cactus that occur in different ecosystems in Northeast Brazil. Seed Science Research 27:292-302.

Llanes A et al. 2016. Alterations of endogenous hormonal levels in plants under drought and salinity. American Journal of Plant Sciences 7:1357-1371.

Marschner H. 1995. Mineral Nutrition of Higher Plants. Academic Press: London.

Meiado MV et al. 2015. Ecological Attributes, Geographic Distribution, and Endemism of Cacti from the São Francisco Watershed. Gaia Scientia 9:40-53.

Meiado MV et al. 2016. Effects of light and temperature on seed germination of cacti of Brazilian ecosystems. Plant Species Biology 31:87-97.

Oliveira GE et al. 2013. Physiological quality and amylase enzyme expression in maize seeds. Ciência e Agrotecnologia 37:40-48.

Rajjou L et al. 2012. Seed germination and vigor. Annual Review of Plant Biology 63:507-533.

Ranal MA and Santana DG. 2006. How and why to measure the germination process? Revista Brasileira de Botânica 29:1-11.

Ranal MA et al. 2009. Calculating germination measurements and organizing spreadsheets. Revista Brasileira de Botânica 32:849-855.

Ryu H and Cho YG. 2015. Plant hormones in salt stress tolerance. Journal of Plant Biology 58:147-155.

Santos AM et al. 2018. Auto-organização da vegetação de caatinga em áreas salinizadas no município de Petrolina-PE. Scientia Plena 14:112.

Siddiqui $\mathrm{MH}$ et al. 2008. Role of nitrogen and gibberellic acid $\left(\mathrm{GA}_{3}\right)$ in the regulation of enzyme activities and in osmoprotectant accumulation in Brassica juncea L. under salt stress. Journal of Agronomy and Crop Science 194:214-224.

Steinbrecher T and Leubner-Metzger G. 2017. The biomechanics of seed germination. Journal of Experimental Botany 68:765-783.

Taylor N and Zappi D. 2004. Cacti of Eastern Brazil. Kew: The Royal Botanic Gardens.

Zappi D et al. 2015. Cactaceae - Lista de Espécies da Flora do Brasil. Rio de Janeiro: Jardim Botânico do Rio de Janeiro. 